\title{
An economical non-destructive method for estimating eelgrass, Zostera marina (Potamogetonaceae) leaf growth rates: formal development and use in northwestern Baja California
}

\author{
Elena Solana-Arellano ${ }^{1}$, Héctor Echavarria-Heras ${ }^{1} \&$ Ernesto Franco-Vizcaíno ${ }^{2}$ \\ 1. Departamento de Ecología Marina, Centro de Investigación Científica y Educación Superior de Ensenada, P.O. Box \\ 434844, San Diego CA. 92143-4844, California, USA; esolana@cicese.mx; hechvar@cicese.mx \\ 2. Departamento de Biología de la Conservación, Centro de Investigación Científica y Educación Superior de Ensenada, \\ P.O. Box 434844, San Diego CA. 92143-4844, California, USA; franco@cicese.mx
}

Received 21-VI-2006. Corrected 30-VI-2008. Accepted 31-VII-2008.

\begin{abstract}
Seagrass beds provide much of the primary production in estuaries; host many fishes and fish larvae, and abate erosion. The present study presents original analytical methods for estimating mean leaf-growth rates of eelgrass (Zostera marina). The method was calibrated by using data collected in a Z. marina meadow at Punta Banda estuary in Baja California, Mexico. The analytical assessments were based on measurements of leaf length and standard regression procedures. We present a detailed explanation of the formal procedures involved in the derivation of these analytical methods. The measured daily leaf-growth rate was $10.9 \mathrm{~mm} \mathrm{~d}^{-1}$ leaf $^{-1}$. The corresponding value projected by our method was $10.2 \mathrm{~mm} \mathrm{~d}^{-1}$ leaf ${ }^{-1}$. The associated standard errors were of 0.53 and $0.56 \mathrm{~mm} \mathrm{~d}^{-1}$ leaf $^{-1}$ respectively. The method was validated by projecting leaf-growth rates from an independent data set, which gave consistent results. The use of the method to obtain the mean leaf growth rate of a transplanted plot is also illustrated. Comparison of our leaf-growth data with previously reported assessments show the significant forcing of sea-surface temperature on eelgrass leaf dynamics. The formal constructs provided here are of general scope and can be applied to equivalent eelgrass data sets in a straightforward manner. Rev. Biol. Trop. 56 (3): 1003-1013. Epub 2008 September 30.
\end{abstract}

Key words: eelgrass, growth rates, analytical estimations.

Seagrass beds are indicators of the status of the coastal zone and can be used in management strategies that aim to preserve or improve environmental quality. Nutrient cycling represents a large proportion of the environmental services performed by estuaries and seagrass beds (Wharton 1970, Gosselink et al. 1974, Costanza et al. 1997). In particular, eelgrass populations provide substantial amounts of organic material to the shallow-water food web, as well as habitat or shelter for many fishes and fish larvae (McRoy 1966).

Sea-surface temperature exerts a strong influence on the dynamics of marine ecosystems (Tegner and Dayton 1987, Baumgartner et al. 1992, Beer and Koch 1996, Holbrook et al.
1997, Johnson et al. 2003). For eelgrass, water temperature drives the accumulation of aboveground biomass (Poumian-Tapia and IbarraObando 1999), and is highly correlated with leaf dynamics (Solana-Arellano et al. 1997, Short and Neckles 1999, Solana-Arellano et al. 2004). Sea-surface temperature has been reported to control the seasonal cycle of eelgrass growth (Rasmmussen 1977, Phillips and Backman 1983). There is also a widespread belief that both the distribution and abundance of seagrasses in temperate littoral waters are tightly linked to light availability (Backman and Barilotti 1976, Dennison and Alberte 1982, 1985, 1986, Bulthuis and Woelkerling 1983, Orth and Moore 1983, 1988, Zimmerman et al. 
1991, Cabello-Pasini et al. 2002). Data collected at our study site in Punta Banda corroborate that sea surface temperature, light availability and dissolved nutrients are key environmental factors that control leaf dynamics in eelgrass (Solana-Arellano et al. 2004). A principalcomponent analysis resulted in a highest correlation coefficient for sea-surface temperature $(\mathrm{r}=0.86)$, while light radiation also had a high correlation coefficient $(\mathrm{r}=0.72)$. Together these two variables explain $49 \%$ of the variability induced by all abiotic variables.

Changes in the global climate are expected to alter sea-surface temperature, underwater light flux, and the availability of dissolved nutrients, and thus may severely affect both the structure and the dynamics of seagrass beds (Cambridge and McComb 1984, Valiela et al. 1992, Peterson et al. 1993, Short and Neckles 1999). In addition to adverse climatic influences, coastal development represents an additional threat to the health and extent of seagrass beds that could result in irreversible alterations. The ecological importance of seagrasses has driven efforts to conserve and expand existing communities, restore lost ones and create new ones. Indeed, several workers have developed various techniques for transplanting seagrass species (Fredette et al. 1985, Fonseca et al. 1986, Lewis 1987, Fonseca et al. 1996).

The disruptive effects of coastal development are evident in many estuaries and salt marshes throughout adjacent southern California, USA (Fong and Zedler 2000, Linding-Cisneros and Zedler 2000, Werner and Zedler 2002). Human activities in Baja California (Mexico) wetlands and estuaries have accelerated in the last decades. The first structural modification of an estuary on the Pacific coast of the peninsula was the 1983 construction of an oil-industry tidal exclusion in the Punta Banda estuary, which resulted in the disappearance of vegetation within the affected area. Prior to 1979, the site was practically undisturbed and had extensive coverage of eelgrass (Aguilar-Rosas 1980). Eelgrass populations within the remaining tidal zone were considered depleted by 1983 (Cabello-Pasini
1984) because of burial provoked by heavy storms that occurred during 1978-1981. Transplantation of $Z$. marina shoots from a nearby estuary has been contemplated as a way to promote the recovery of the depleted $Z$. marina beds at our study site (Cabello-Pasini 1984, Solana-Arellano et al. 2002).

Data on structural and dynamical aspects of vegetation in re-established wetlands are required to provide evidence that restoration efforts have met predefined goals. The rate of change for leaf length in Zostera marina has been considered as a response variable to environmental influences (Jacobs 1979, Phillips and Backman 1983, Short and McRoy 1984). The leaf architecture of $Z$. marina makes length a determinant of both leaf area and weight (Solana-Arellano et al. 2003). Hence the characterization of the corresponding leaf-growth rates provides valuable ecological information.

Studies on leaf dynamics of seagrasses have generally been descriptive (Sand-Jensen 1975, Jacobs 1979, Ott 1980, Aioi et al. 1981, Umebayashi 1988, Aioi and Pollard 1993). Methods for the analytical assessment of leaf growth are scarce in the literature. The first analytical study on growth rates for sea grasses was developed by Patriquin (1973), who proposed a linear model for the mean growth rate of previously marked shoots of Thalassia testudinum. Solana-Arellano et al. (1997) studied the dynamics of leaf growth rates for $Z$. marina through a generalization of the monomolecular model.

Due to seasonality effects, the study of representative variables of leaf dynamics in $Z$. marina demands extensive sampling during the entire yearly cycle. Traditional methods for the assessment of eelgrass leaf-growth rates require tedious leaf-marking techniques and time-consuming laboratory work. These procedures can induce high shoot loss, particularly in restored areas. In the present study we introduce analytical tools for the estimation of mean leaf-growth rates and their associated uncertainties. The results show that these indirect assessments produce consistent outcomes for both natural 
and transplanted eelgrass populations at our study site.

\section{MATERIALS AND METHODS}

Study site: the data used to calibrate the analytical method developed in this paper were collected biweekly from January through December 2000 in a Z. marina meadow in Punta Banda estuary, located near Ensenada, Baja California, Mexico (31 $40^{\prime} \mathrm{N}-31^{\circ} 48^{\prime}$ $\mathrm{N}$ and $\left.116^{\circ} 37^{\prime} \mathrm{W}-116^{\circ} 40^{\prime} \mathrm{W}\right)$. A complete description of the study site is given in SolanaArellano et al. (2000).

Field laboratory and statistical methods: following a complete random sample design, we marked 20 shoots during each sampling date, using the technique of Kentula and McIntire (1986). After two weeks, we harvested the previously marked shoots and marked a new set of 20 shoots. The samples were taken to the laboratory where measurements of length (mm), width ( $\mathrm{mm})$, and dry weight (g) were made on each leaf. Individual mean leaf-growth rates, expressed as $m m d^{-1}$, were calculated by dividing leaf elongation by the number of days of growth. We collected a total of 600 shoots and 2263 complete leaves for the analysis. Curve fittings were made by using non-linear regression in the statistical package STATISTICA (1999).

The analytical mean leaf-growth rate projection method: for the constructs presented throughout this work, the following definitions and notations are required. Let $l(t)$ be the length of a $Z$. marina leaf at time $t$. The number of $Z$. marina leaves contained in a shoot sample taken at time $t_{i}$ with $t_{0} \leq t_{i} \leq t_{F}$ will be denoted by $N\left(t_{i}\right)$. For $\mathrm{j}=1, \ldots \ldots N\left(t_{i}\right)$ let $l_{j}\left(t_{i}\right)$ stand for the length of the $j^{\text {th }}$ leaf in the sample. The symbol $\alpha_{l}\left(t_{i}\right)$ will denote the expected value of $l_{j}\left(t_{i}\right)$ over the distribution of leaf lengths. The corresponding variances will be denoted by means of $\beta^{2}{ }_{l}\left(t_{i}\right)$. Similarly $\Delta\left(t_{i}, t_{i+1}\right)$ will stand for the time increment $\left(t_{i+1}-t_{i}\right)$, while the symbol $\Delta l_{j}\left(t_{i}, t_{i+1}\right)$ will denote the leaf length increment $\left(l_{j}\left(t_{i+1}\right)-l_{j}\left(t_{j}\right)\right)$. Thus, for the $\mathrm{j}^{\text {th }}$ leaf, the mean leaf growth rate (MLGR) over the interval $\left(t_{i}, t_{i+1}\right)$ is defined by,

$$
\frac{\Delta l_{j}\left(t_{i}, t_{i+1}\right)}{\Delta\left(t_{i}, t_{i+1}\right)}=\frac{l_{j}\left(t_{i+1}\right)-l_{j}\left(t_{i}\right)}{\left(t_{i+1}-t_{i}\right)}
$$

The expected value over the associated variation range of these MLGR will be denoted by the symbol $\alpha_{r l}\left(t_{i}, t_{i+1}\right)$. Correspondingly, the variance of these MLGR in equation (3.1) will be represented by means of the symbol $\beta_{r l}^{2}\left(t_{i}, t_{i+1}\right)$.

Suppose that a leaf survives the deleterious effects of drag forces or herbivory. Then its growth could take place continuously over a suitable period of time. Therefore, it is reasonable to assume that there exists a longitudinal asymptotic maximum size $l_{\infty}$, which is the maximum length attained in the limit when time approaches infinity. This is a standard assumption in growth models (Von Vertalanffy 1957, Richards 1959, Seber and Wild 1988), and corresponds to a simplification that can be tested by empirical validation. Solana-Arellano et al. (1997) used this framework and demonstrated that leaf dynamics in $Z$. marina could be modeled through a generalization of the traditional monomolecular model. They demonstrated that the associated asymptotic specific-growth rate can be expressed as an environmental forcing function of temperature, underwater light flux, and dissolved nutrients. In this section, we will also invoke the monomolecular growth assumption, and use it to derive an original analytical method for the projection of the pertinent MLGR values. We assume that $l(t)$ can be modeled by means of the equation

$$
\frac{d l}{d t}=\varnothing(t)\left(l_{\infty}-l(t)\right)
$$

where $\varnothing(t)$ stands for an environmental forcing factor. Separation of variables and integration from $t_{i}$ to $t_{i+1}$ produces the equivalent equation,

$\ln \left(\frac{l_{\infty}-l_{j}\left(t_{i+1}\right)}{l_{\infty}-l_{j}\left(t_{i}\right)}\right)=-\int_{t_{i}}^{t_{i+1}} \phi(u) d u$. 
Taking exponentials on both sides and rearranging we have,

$$
l_{j}\left(t_{i+1}\right)=l_{\infty}-\left(l_{\infty}-l_{j}\left(t_{i}\right)\right) \exp \left(-\int_{t_{i}}^{t_{i+1}} \phi(u) d u\right)
$$

Subtracting $l_{j}\left(t_{i}\right)$ from both sides of equation (3.4), we get an analytical representation for the individual MLGR in equation (3.1). It becomes,

$$
\frac{\Delta l_{j}\left(\mathrm{t}_{i}, t_{i+1}\right)}{\Delta\left(t_{i}, t_{i+1}\right)}=\frac{\left(1_{\infty}-l_{j}\left(t_{i}\right)\right)}{\Delta\left(t_{i}, t_{i+1}\right)}\left(1-\exp \left(-\int_{t_{i}}^{t_{i+1}} \phi(u) d u\right)\right)
$$

Obtaining the expected value on both sides of the above equation will produce analytically determined values for $\alpha_{r l}\left(t_{i}, t_{i+1}\right)$, these will be expressed in terms of $\alpha_{l}\left(t_{i}\right)$, the expected value of leaf length at a time $t_{i}$, the asymptotic length $l_{\infty}$ and the scaling function $\varnothing(t)$. Formally,

$$
\alpha_{r l}\left(t_{i}, t_{i+1}\right)=\frac{\left(l_{\infty}-\alpha_{l}\left(t_{i}\right)\right)}{\Delta\left(t_{i}, t_{i+1}\right)}\left(1-\exp \left(-\int_{t_{i}}^{t_{i+1}} \phi(u) d u\right)\right)
$$

By a direct calculation of the variance on both sides of equation (3.5) we get an expression of $\beta_{r l}^{2}\left(t_{i}, t_{i+1}\right)$, which represents the projected variance for the MLGR over the interval $t_{i}<t<t_{i+1}$. It becomes,

$\beta_{r l}^{2}\left(t_{i}, t_{i+1}\right)=\left(\frac{1-\exp \left(-\int_{t_{i}}^{t_{i+1}} \phi(u) d u\right)}{\Delta\left(t_{i}, t_{i+1}\right)}\right)^{2} \beta_{l}^{2}\left(t_{i}\right)$

The analytically defined values of equation (3.6) and (3.7) are based on both the $\alpha_{l}\left(t_{i}\right)$ data and on the values that the scaling factor $\varnothing(t)$ attains at each sampling time $t_{i}$ Directly obtained leaf-length values determine sample values for $\alpha_{l}\left(t_{i}\right)$. We will propose a method to estimate the factor $\varnothing(t)$ which can be identified by means of standard regression procedures, using leaf length data. To obtain that device, we observe that if we define a continuous function $r(t)$ through the expression

$$
r(t)=\frac{\phi(t)\left(l_{\infty}-l(t)\right)}{l(t)}
$$

then equation (3.2) can be reparametrized into the form

$$
\frac{d l}{d t}=r(t) l(t)
$$

Then separation of variables and integration from $t_{0}$ to $t_{i+1}$ yields for the $\mathrm{j}^{\text {th }}$ leaf in a sample

$$
l_{j}\left(t_{i+1}\right)=l_{j o}\left(t_{i+1}\right) \exp \left(\int_{t_{i}}^{t_{i+1}} r(u) d u,\right.
$$

where $l_{j 0}\left(t_{i+1}\right)$ stands for the length that the $\mathrm{j}^{\text {th }}$ leaf in the sample taken at time $t_{i+1}$ had at the initial sampling time $t_{0}$. Similarly, integration from $t_{0}$ to $t_{i}$ produces,

$$
l_{j}\left(t_{i}\right)=l_{j 0}\left(t_{i}\right) \exp \left(\int_{t_{0}}^{t_{i}} r(u) d u\right)
$$

Form the above equations, mathematical expectation gives

$$
\alpha_{l}\left(t_{i}\right)=\alpha_{l 0}\left(t_{i}\right) \exp \left(\int_{t_{0}}^{t_{i}} r(u) d u\right)
$$

and

$$
\alpha_{l}\left(t_{i+1}\right)=\alpha_{l 0}\left(t_{i+1}\right) \exp \left(\int_{t_{0}}^{t_{i+1}} r(u) d u\right)
$$


In the above equations $\alpha_{l 0}\left(t_{i}\right)$ and $\alpha_{l 0}\left(t_{i+1}\right)$ represent the expected values of the random variables $l_{j 0}\left(t_{i}\right)$ and $l_{j 0}\left(t_{i+1}\right)$ respectively. Combining equation (3.12) and (3.13) we get,

$$
\alpha_{l}\left(t_{i+1}\right)=\alpha_{l}\left(t_{i}\right) s\left(t_{i}\right) \quad \exp \left(\int_{t_{i}}^{t_{i+1}} r(u) d u\right)
$$

where

$$
s\left(t_{i}\right)=\frac{\alpha_{l 0}\left(t_{i+1}\right)}{\alpha_{l 0}\left(t_{i}\right)}
$$

Following Charles-Edwards et al. (1986) and Solana Arellano et al. (1997), we can assume that seasonal influences on leaf growth induce a periodic behavior for the functions $s(t)$ and $r(t)$. These functions can be approximated by means of trigonometric polynomials (cf. equation (5.9.10) in Batschelet (1974)). Formally, $r(\mathrm{t})$ and $\mathrm{s}(\mathrm{t})$ can be assumed to have the empirical form,

$$
r(t)=a_{r 0}+\sum_{k=1}^{m} a_{r k} \cos \left(c_{r} t\right)+b_{r k} \sin \left(c_{r} t\right)
$$

$$
s(t)=a_{s 0}+\sum_{k=1}^{n} a_{s k} \cos \left(c_{s} t\right)+b_{s k} \sin \left(c_{s} t\right)
$$

where $c_{\mathrm{r}}$ and $\mathrm{c}_{\mathrm{s}}$ as well as $\mathrm{a}_{\mathrm{rk}}, \mathrm{a}_{\mathrm{sk}}, \mathrm{b}_{\mathrm{rk}}$ and $\mathrm{b}_{\mathrm{sk}}$ for $\mathrm{k}=0,1, \ldots . \mathrm{m}$ or $\mathrm{n}$ are parameters, with $\mathrm{m}$, and $\mathrm{n}$ being the orders of the trigonometric polynomials under consideration.

These projection procedures can be summarized in the following steps. We first obtain an estimate for the maximum asymptotic length directly from observations. That is, we assume that $l_{\infty}$ is represented by the maximum value that $l(t)$ has attained over a long period of observations. Then, we assume that $r(t)$ and $s(t)$ are given by trigonometric polynomials (cf. equations (3.15) and (3.16)), and perform the fitting of the resulting equation (3.14) by using values for $\alpha_{l}\left(t_{i}\right)$ determined from samples. This will provide an identified form for $r(t)$ and through the use of equation (3.8) we can obtain an estimate of $\varnothing(t)$. We then use these estimations, along with the values for $\alpha_{l}\left(t_{i}\right)$ determined from samples to produce, by means of equation (3.6), the corresponding projected average MLGR values. The associated projected variances $\beta_{r l}^{2}\left(t_{i}, t_{i+1}\right)$ are given by the pertinent procedures defined by equation (3.7).

\section{RESULTS}

Projected mean leaf growth rate values: for the projection of MLGR we used a maximum leaf length of $863 \mathrm{~mm}$, which was reached after 32 months of observation in November 1998 (Solana-Arellano 2004). This value was used as an estimation for $l_{\infty}$. To find expressions for both $r(t)$ and $s(t)$ (and assuming they have a trigonometric polynomial representation (cf. eq. (3.15) and (3.16)), we fitted equation (3.14) by using values for $\alpha_{l}\left(t_{i}\right)$ derived from samples. For this fitting, the stationary case of $r(t)$ in equation (3.15) produced the highest determination coefficient, a value of $R^{2}=0.84$. A statistical analysis of the residuals show normality $\left(\chi^{2} p>0.05\right)$ and homoscedasticity (Fisher $\mathrm{F}=1.6$ test $\mathrm{p}=0.23$ ). This means that there was good correspondence between the observed and fitted values (Fig. 1)

The estimated form of $r(t)$ obtained in the fitting of equation (3.14) was substituted into equation (3.8) to get an estimated form of the environmental scaling factor $\varnothing(t)$. Monthly leaf-growth rates were then projected by using equation (3.6) (Fig. 2). The associated variances projected through equation (3.7) are shown in Fig. 3. The observed monthly values for the MLGR produced an overall daily average of $10.9 \mathrm{~mm}_{\text {day }}{ }^{-1}$ leaf $^{-1}$ with a standard error of $0.53 \mathrm{~mm}$ day $^{-1}$ leaf $^{-1}$. The corresponding projected values produced an average of 10.2 $\mathrm{mm}$ day $^{-1}$ leaf $^{-1}$ with an associated standard error of $0.56 \mathrm{~mm}$ day $^{-1}$ leaf $^{-1}$. We performed a $\chi^{2}$ test and found no differences $(\mathrm{p}=0.997)$ between observed monthly averages and the 


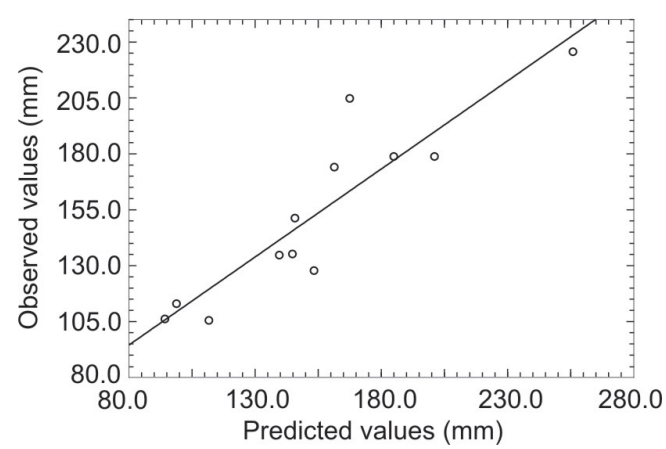

Fig. 1. Predicted against observed values for the fitting of equation (3.14) with resulting $R^{2}=0.84$. This fitting produced the estimated parameters for the representation of $r(t)$ and $\mathrm{s}(\mathrm{t})$ as given in equations (3.15) and (3.16). Fitted parameter values for s(t) were $a_{x 0}=1.4, a_{s 1}=0.08, a_{s 2}=$ $-0.08, b_{s 1}=-0.04, b_{s 2}=0.03$ and $c_{s}=3.2$. For $\mathrm{r}(\mathrm{t})$ a stationary representation produced $a_{r 0}=0.86$ with the highest determination coefficient. The estimated forcing factor $\varnothing(t)$ obtained by replacing the identified form of $r(t)$ into equation (3.8) produced, through the use of equation (3.6), the projected rates in Fig. 2.

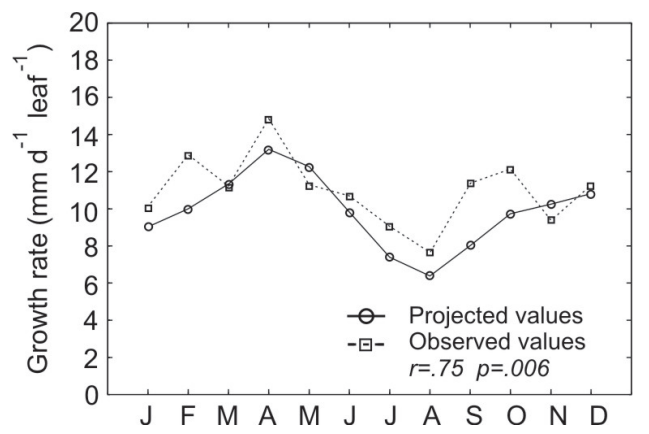

Fig. 2. Projected and observed mean daily leaf growth rates through time. These projections were obtained by substituting the estimated form of $ø(t)$ into equation (3.6), using available leaf-length data. The suitability of both model (3.2) and the sample based estimation of $l_{\infty}$ can be used to explain the differences between observed and projected values. Both time series have the same statistical properties, which was corroborated by means of a $\chi^{2}$ test.

corresponding values projected through equation (3.6).

Application to an independent data set: Cabello-Pasini et al. (2002) evaluated the effects of storms on photosynthesis, carbohydrate

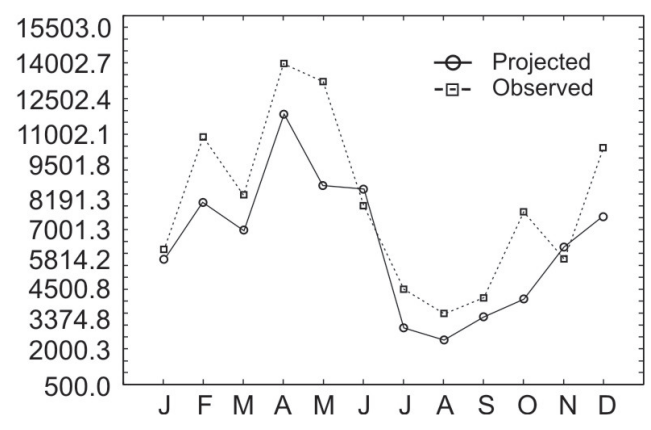

Fig. 3. Projected and observed monthly variance values for mean growth rates. The projected variances were calculated by means of equation (3.7) using leaf-length data and the identified form of $\varnothing(t)$.

content and survival of seagrass at Punta Banda estuary and estimated a value of $4.8 \pm 0.8 \% d^{-1}$ as the average specific leaf-growth rate. Using their leaf-length data and the estimated form of the environmental factor $\varnothing(t)$ determined from our data, we projected the corresponding MLGR through equation (3.6) and obtained a specific growth rate of $4.2 \pm 0.02 \mathrm{~mm} \mathrm{day}^{-1}$. This result shows that our analytical projection method gives consistent results when applied to data from similar $Z$. marina meadows.

Application to transplanted plot data: the projection method was also used to estimate MLGR for an experimental transplant at our study site. Removal of shoots was necessary four months after planting due to an infestation of the bryozoan Zoobotrion verticillatum which dramatically reduced light availability in the water column (Solana-Arellano et al. 2002). Using the fitted form of $\varnothing(t)$ and the corresponding average leaf length, we projected a mean leaf growth rate of $14.4 \mathrm{~mm}$ day $^{-1}$ leaf $^{-1}$ for this transplant. This value was similar to the maximum monthly observed rate in the natural population (Fig. 2). Moreover, the allometric model of Solana-Arellano et al. (1998), which expresses leaf-dry weight in terms of the corresponding area, was fitted to the harvest data. No significant differences were found in the scaling parameters with respect to leaves 
growing in the natural meadow. This result, along with a consistent value for MLGR, suggests that the transplanted shoots were growing in the same manner as those in the natural environment.

\section{DISCUSSION}

Most of the methods used to study growth and production in marine phanerogams are expensive, time consuming, and require destructive techniques such as leaf marking (Sand-Jensen 1975, Jacobs 1979). Excessive manipulation of raw material also increases the error introduced into the data (Mandel 1964). Our indirect estimations, which we call analytical projections, are based on measurements of leaf length and a scaling factor associated with environmental forcing. This factor can be obtained directly from observed leaf-length data using regression procedures. Hence, the resulting characterizations can reduce research expenses by simplifying assessment techniques.

The analytical assessment method introduced here was adapted from the model of equation (3.2), which has the advantage of linearity (i.e, the individual leaf growth rates depend linearly on leaf length). This property assures that the asymptotic growth assumption is maintained for the corresponding averages. Another feature of the linearity in equation (3.2) is its implied structural stability. That is, small perturbations in either the forcing function $\varnothing(t)$ or the parameter $l_{\infty}$ will produce small deviations in the projected MLGR values.

The deviations between projected and observed values in Fig. 2 can be explained in terms of both the determination coefficient of the fitting and also on the suitability of the estimated value for $l_{\infty}$. Whenever the fitting of equation (3.13) fails to be robust, and the estimation of $l_{\infty}$ is not representative of its true value, equation (3.8) will fail to produce realistic values for the forcing factor $\varnothing(t)$. In those cases, the projection is not expected to represent the general properties of the observed time series. Our analytical method is thus highly sensitive to the adequacy of the asymptotic growth assumption of model (3.2). Moreover, the sampling design must provide a representative stream of leaf-length data, which is crucial for a sound identification of the asymptotic length. Thus, the time-scale of observation is an important issue for the identification task and for the reduction of degrees of freedom. These provisions should afford a sound basis for the identification of both $l_{\infty}$ and the environmental scaling factor $\varnothing(t)$.

Because Z. marina shoots are renewed about once a year (Olesen and Sand-Jensen 1994), this time span of observations provides for the proper estimation of the asymptotic length, as well as sufficient data for the fitting of equation (3.14). To achieve this step, we relied on data for whole leaves as required by the asymptotic growth assumption. Although incomplete leaves could be used to measure elongation between sampling dates, and therefore provide an accurate statistic of mean leafgrowth rate, this will fail to identify the size of the leaf relative to the asymptotic length in an unambiguous way. This is a fundamental entry in all asymptotic growth models, since the closer the leaf is to the asymptotic length, the smaller its growth rate is expected to be. Further, Ibarra-Obando and Boudouresque (1994) and Ibarra-Obando et al. (1997) have stated that the use of whole leaves should allow a better identification of seasonal trends, which affect leaf growth and shoot morphometrics in eelgrass. Hence, it was assumed that the use of whole leaves permitted a more realistic characterization of the environmental forcing factor $r(t)$.

The observed time series of mean leafgrowth rates is a sample path of an underlying causal stochastic process (Hoel et al. 1972). In that sense, the projected time series must have the same statistical properties, including the same expected value, over the whole sample space. To test this we performed a $\chi^{2}$ test, which indicated no significant differences between observed and projected values. We also found a remarkable consistency in the projected value for the annual average rate of leaf growth, which was virtually the same as the one 
we calculated from field data. Moreover, using leaf-length data in Cabello-Pasini et al. (2002), we projected the corresponding specific growth rates and found a good correspondence with the mean reported by those workers. The application of our projection method to the transplant experiment data in Solana Arellano et al. (2002) permitted us to obtain a non-destructive characterization of the associated MLGR and to infer about differences in growth parameters between the transplanted and the natural populations. This provides another example of the advantages of the method for indirect estimation methods presented here.

Hence, we conclude that our indirect estimation method is expected to be particularly useful for protected or transplanted areas where the effects of sampling could be deleterious. For natural populations where the effect of sampling may not be an issue, our constructs could simplify the traditional estimation procedures based on leaf marking techniques. Moreover, our method could be successfully applied to other seagrass species which have leaf growth dynamics similar to eelgrass, where leaf width can be considered as roughly constant after an initial growth stage.

Since Z. marina is a temperate-climate species, it is reasonable to expect that values of standing-stock variables will be higher during La Niña (cooler water) than El Niño (warmer water) events. For example, Ibarra-Obando and Huerta-Tamayo (1987) reported an average mean leaf-growth rate of $8.4 \mathrm{~mm} \mathrm{~d}^{-1}$ on the basis of data obtained at San Quintín Bay (an estuary $100 \mathrm{~km}$ south of our study site) during 1982, one of the strongest ENSO events reported to date, when annual mean sea-surface temperature was $20^{\circ} \mathrm{C}$ (http://ingrid.ldeo.columbia.edu/ SOURCES/.CAC/.sst/). Using our method, the corresponding projected values is $10.2 \mathrm{~mm} \mathrm{~d}^{-1}$. Also for San Quintín Bay, Ibarra-Obando et al. (1997) reported averages of $85.03 \mathrm{~mm}$ for leaf length and an average leaf dry weight of 0.01 $g$ during the ENSO event of 1987 when annual mean sea-surface temperature was $18.4^{\circ} \mathrm{C}$. Our estimates of these variables were $1.54 \mathrm{~mm}$ and
$0.015 \mathrm{~g}$, respectively. It should be noted that the data used in this study were obtained in 2000, a year that presented negative sea-surface temperature anomalies and annual mean temperature was $16.4^{\circ} \mathrm{C}$ (http://ingrid.ldeo.columbia. edu/SOURCES/.CAC/.sst/).

For leaf turnover, Ibarra-Obando et al. (1997) reported a value of $9.7 y r^{-1}$. Other authors have found similar values in other eelgrass populations (Duarte 1991). Short eelgrass turnover times may have induced a short delay response to more favorable, cooler sea-surface temperatures, in such a way that the larger values in our data can be explained. Differences between standing-stock data presented in this study and similar variables published by other workers are likely the result of differences in sea-surface temperatures during the periods sampled (Short and Neckless 1999). Thus, comparison of our standing-stock data with previously reported assessments suggest the significant forcing effect of sea-surface temperature on eelgrass leaf dynamics.

Global climate change is expected to result in reduced productivity of seagrasses because of higher sea-surface temperatures. Moreover, accelerating economic development along the coastline of the US-Mexico border region assures continued human impacts on seagrass communities. The importance of these ecosystems will certainly promote restoration efforts, and the monitoring of such projects will require the design of cost-effective and non-destructive procedures (Phinn et al. 1999). This paper is aimed at contributing towards that objective.

\section{ACKNOWLEDGMENTS}

This paper is part of the research on eelgrass production partially funded by the Mexican National Council on Science and Technology (CONACYT) through grant 26665B. We thank Olga Flores-Uzeta and Cecilia Leal- Ramirez for their technical assistance and José Ma. Dominguez and Francisco Ponce for the fine art work. 


\section{RESUMEN}

Las praderas de pastos marinos abaten la erosión y aportan gran parte de la productividad primaria de los esteros y son refugio de muchos peces y sus larvas. El presente trabajo introduce métodos analíticos para estimar las tasas medias de crecimiento foliar de Zostera marina $\mathrm{L}$. y sus varianzas. La calibración del método se llevó a cabo utilizando datos de una pradera de esta fanerógama en el Estero de Punta Banda Baja California, México. Las referidas estimaciones analíticas, se basan en medias de longitud foliar y en procedimientos estandarizados de regresión. Dichas determinaciones son por ende no-destructivas. Se proporciona una explicación detallada de los aspectos formales de la derivación del método. El valor promedio observado de la tasa media diaria de crecimiento foliar fue de $10.9 \mathrm{~mm} \mathrm{~d}^{-1}$ leaf $^{-1}$. El valor correspondiente proyectado mediante nuestro método fue de $10.2 \mathrm{~mm} \mathrm{~d}^{-1}$ leaf ${ }^{-1}$. Los errores estándar asociados fueron 0.53 y $0.56 \mathrm{~mm} \mathrm{~d}^{-1}$ leaf $^{-1}$ respectivamente. Valores proyectados de la tasa media de crecimiento foliar diario utilizando datos de longitudes foliares publicadas por otros autores dieron también resultados consistentes. Se ilustra también el uso del método para proyectar la media de crecimiento foliar de una parcela transplantada de Zostera marina. La comparación de los resultados de este estudio con equivalentes reportados previamente nos permite concluir que las diferencias observadas pueden ser explicadas en función de la variabilidad de la temperatura superficial del mar en virtud del control de esta variable sobre la dinámica foliar de Z. marina. Las herramientas de estimación indirecta presentadas en este trabajo pueden aplicarse fácilmente a datos equivalentes de Z. marina.

Palabras clave: Zostera marina, tasa de crecimiento foliar, estimaciones analíticas.

\section{REFERENCES}

Aguilar-Rosas, R. 1980. Algas bentónicas y fanerógamas del estero de Punta Banda Baja California durante verano y otoño. Licentiate thesis, Universidad Autónoma de Baja California, Ensenada, Baja California, Mexico.

Aioi, K., H. Mukai, I. Koike, M. Ohtsu \& A. Hattori. 1981. Growth and organic production of eelgrass (Zostera marina L.) in temperate waters of the Pacific coast of Japan. II Growth analysis in winter. Aquat. Bot. 10: $175-182$.

Aioi, K. \& P.C. Pollard. 1993. Biomass, leaf growth and loss rate of the seagrass Syringodium isoetifolium on Dravuni Island, Fiji. Aquat. Bot. 46: 283-292.

Backman, T.W. \& D.C. Barilotti. 1976. Irradiance reduction: effects on standing crop of the eelgrass Zostera marina in a coastal lagoon. Mar. Biol. 34: 33-40.
Baumgartner, T.R., A. Soutar \& V. Ferreira-Bartrina. 1992. Reconstruction of the history of Pacific sardine and northern anchovy populations over the past two millennia from sediments of the Santa Barbara Basin, California. CalCOFI Rep. 33: 24-40.

Batschelet, E. 1974. Ordinary differential equations, p. 305-307. In Springer Verlag (ed.). Introduction to mathematics for life scientists. Springer Verlag, New York, USA.

Beer, S. \& E.W. Koch. 1996. Photosynthesis of marine macroalgae and seagrasses in globally changing $\mathrm{CO}_{2}$ environments. Mar. Ecol. Prog. Ser. 41: 199-204.

Bulthuis, D.A. \& W.J. Woelkerling. 1983. Seasonal variations in standing crop, density and leaf growth of the seagrass Heterozostera tasmanica, in Western Port, Victoria, Australia. Aquat. Bot. 16: 111-136.

Cabello-Pasini, A. 1984. Transplantes de Zostera marina L. en el estero de Punta Banda, Baja California Mexico, durante el verano de 1983 y su comportamiento a través de otoño e invierno. Licentiate thesis, Universidad Autónoma de Baja California, Ensenada, Baja California, Mexico.

Cabello-Pasini, A., C. Lara-Turrent \& R.C. Zimmerman. 2002. Effect of the storms on photosynthesis, carbohydrates and survival of eelgrass populations from a coastal lagoon and the adjacent open sea. Aquat. Bot. 74: 149-164.

Cambridge, M.L. \& A.J. McComb. 1984. The loss of seagrasses in Cockburn Sound, Western Australia. I. The time course and magnitude of seagrass decline in relation to industrial development. Aquat. Bot. 20: 229-243.

Charles-Edwars, D.A., D. Doyle \& G.M. Rimmington. 1986. Modeling Plant Growth and Development, Academic Press, San Diego, California, USA.

Costanza, R., R. d'Arge, R. de Groot, S. Farber, M. Garsso, B. Hannon, K. Limburg, S. Naeem, R.V. O’Neill, J. Paruelo, R.G. Raskin, P. Sutton \& M. van den Belt. 1997. The value of the world's ecosystem services and natural capital. Nature 387: 253-259.

Dennison, W.C. \& R.S. Alberte. 1982. Photosynthetic response of Zostera marina L. (eelgrass) to in situ manipulations of light intensity. Oecologia 55: $137-$ 144.

Dennison, W.C. \& R.S. Alberte. 1985. Role of daily light period in the depth distribution of Zostera marina L. (eelgrass). Mar. Ecol. Prog. Ser. 25: 51-61. 
Dennison, W.C. \& R.S. Alberte. 1986. Photoadaptation and growth of Zostera marina L. (eelgrass) transplants along a depth gradient. J. Exp. Mar. Biol. Ecol. 98: 265-282.

Duarte, C.M. 1991. Allometric scaling of seagrass form and productivity. Mar. Ecol. Prog. Ser. 77: 289-300.

Fonseca, M.S., W.J. Kenworthy \& G.W. Thayer. 1986. Restoration and management of seagrass systems: a review, p 1-18. In College of Charleston S.C. International Symposium on Ecology and Management of Wetlands, Wetland Restoration and Regulation Session.

Fonseca, M.S., D.L. Meyer \& M.O. Hall. 1996. Development of planted seagrass beds in Tampa Bay, Florida, USA. II. Faunal components. Mar. Ecol. Prog. Ser. 132: 141-156.

Fong, P. \& J.B. Zedler. 2000. Sources, sinks, and fluxes of nutrients $(\mathrm{N}+\mathrm{P})$ in a small highly urban estuary in southern California. Urban Ecosystems. 4: 124-144.

Fredette, T.J., M.S. Fonseca, W.J. Kenworthy \& G.W. Thayer. 1985. Seagrass transplanting: ten years of U.S. Army Corps research, p. 1-19. In $12^{\text {th }}$ Hillsborough Community College, Tampa, FL. Annual Conf. on Wetland Restoration and Creation, Tampa, Florida, USA.

Gosselink, J.G., E.P. Odum \& R.M. Pope. 1974. The value of the tidal marsh. P1-30. Publ. No. LSUSG-4-03. Center for Wetland Resources, Louisiana State University, Baton Rouge, Louisiana, USA.

Holbrook, S.J., R.J. Schmitt \& J.S. Stephens. 1997. Changes in an assemblage of temperate reed fishes associated with a climate shift. Ecol. Appls. 7: 12991310 .

Hoel, P.G., S.C. Port \& J. Stone 1972. Introduction to stochastic processes. Houghton Mifflin Company Boston MA., Massachusetts, USA.

Ibarra-Obando, S.E. \& R. Huerta-Tamayo. 1987. Blade production of Zostera marina $\mathrm{L}$. during the summerautumn period on the pacific coast of Mexico. Aquat. Bot. 28: 301-315.

Ibarra-Obando, S.E. \& C.F. Boudouresque. 1994. An improvement of the Zieman leaf marking technique for Zostera marina growth and production assessment. Aquat. Bot. 47: 293-302.

Ibarra-Obando, S.E., C.F. Boudouresque \& M. Roux. 1997. Leaf dynamics and production of a Zostera marina bed near its southern limit. Aquat. Bot. 58: 99-112.
Jacobs, R.P.W.M. 1979. Distribution and aspects of the production and biomass of eelgrass, Zostera marina L., at Roscoff, France. Aquat. Bot. 7: 151-172.

Johnson, M.R., S.L. Williams, C.H. Lieberman \& A. Solbak. 2003. Changes in the abundance of the seagrasses Zostera marina L. (eelgrass) and Ruppia maritima L. (widgeongrass) in San Diego, California, following an El Niño event. Estuaries 26: 106-115.

Kentula, M.E. \& C.D. McIntire. 1986. The autoecology and production dynamics of eelgrass (Zostera marina. L.) in Netarts Bay, Oregon. Estuaries 9: 188-199.

Lewis, R.R. III. 1987. The restoration and creation of seagrass meadows in the southeastern United States, $p$ 153-173. In M.J. Durako, R.C. Phillips \& R.R. Lewis III (eds.). Proc. of the Symposium on SubtropicalTropical Seagrasses of the Southeastern United States, Florida. Marine Research, Vol. 42, Florida, USA.

Linding-Cisneros, R. \& J.B. Zedler. 2000. Restoring urban habitats: A comparative study. Ecol. Rest. 18: 184192.

Mandel, J. 1964. Some principles of sampling, p. 224-241. In P. Dover Publications, Inc. The statistical analysis of experimental data. New York, USA.

McRoy, C.P. 1966. The standing stock and ecology of eelgrass (Zostera marina) in Izembek Lagoon Alaska. M.Sc. thesis, University of Washington, Seattle, Washington, USA.

Olesen, B. \& K. Sand-Jensen. 1994. Biomass-density patterns in the temperate seagrass Zostera marina. Mar. Ecol. Prog. Ser. 109: 283-294.

Orth, R.J. \& K.A. Moore. 1983. Chesapeake Bay: an unprecedented decline in submerged aquatic vegetation. Science. 222: 51-53.

Orth, R.J. \& K.A. Moore. 1988. Distribution of Zostera marina L. and Ruppia maritima L. sensu lato along depth gradients in the lower Chesapeake Bay, U.S.A. Aquat. Bot. 32: 291-305.

Ott, J. 1980. Growth and production in Posidonia oceanica (L.) Delile. Mar. Ecol. 1: 47-64.

Patriquin, D.G. 1973. Estimation of growth rate, production and age of the marine angiosperm, Thalassia testudinum. Mar. Biol. 15: 35-46.

Peterson, C.H., R.T. Barber \& G.A. Skilleter. 1993. Global warming and coastal ecosystems response: How Northern and Southern hemispheres may differ in the Eastern Pacific ocean, p. 17-34. In H.A. Mooney, E.R. Fuentes \& B. Kronberg (eds). Early system 
response to global change: Contrast between North and South America. Academic, New York, USA.

Phillips, R.C. \& T.W. Backman. 1983. Phenology and reproductive biology of eelgrass (Zostera marina L.) at Bahia Kino, Sea of Cortez, Mexico. Aquat. Bot. 17: 85-90.

Phinn, S.R., D.A. Stow \& D. Van Mouwerik. 1999. Remotely sensed estimates of vegetation structural characteristics in restored wetlands, Southern California. Photo. Eng. Rem. Sens. 65: 485-493.

Poumian-Tapia, M. \& S.E. Ibarra-Obando. 1999. Demography and biomass of the seagrass Zostera marina in a Mexican coastal lagoon. Estuaries. 22: 837-847.

Rasmmussen, E. 1977. The wasting disease of eelgrass (Zostera marina) and its effects on environmental factors and fauna. In C.P. McRoy, C. Helffrich \& M. Dekker (eds.). Creation of seagrass beds. Seagrass ecosystems, New York, USA.

Richards, F.J. 1959. A flexible growth function for empirical use. J. Exp. Bot. 10: 290-300.

Sand-Jensen, K. 1975. Biomass net production and growth dynamics in an eelgrass (Zostera marina) population in Vellerupo Vig, Denmark. Ophelia 14: 185-201.

Seber, G.A.F. \& C.J. Wild. 1988. Nonlinear regression. John Wiley and Sons, New York, USA.

Short, F.T. \& H.A. Neckles. 1999. The effects of global climate change on seagrasses. Aquat. Bot. 63: 169-196.

Short, F.T. \& C.P. McRoy. 1984. Nitrogen uptake by leaves and roots of the seagrass Zostera marina L. Bot. Mar. 27: 547-555

Solana-Arellano, E., H. Echavarria-Heras \& S.E. IbarraObando. 1997. Leaf size dynamics for Zostera marina L. in San Quintin Bay, Mexico: A theoretical study. Estuar. Coast. Shelf Sci. 44: 351-359.

Solana-Arellano, E., D.J. Borbon-Gonzalez \& H. Echavarria-Heras. 1998. A general allometric model for blade production in Zostera Marina L. Bull. South. Calif. Acad. Sci. 97: 39-48.

Solana-Arellano, E., H. Echavarria-Heras \& O. FloresUzeta. 2000. An upgraded method to relocate marked shoots of the seagrass Zostera marina. Rev. Biol. Trop. 48: 927-930.

Solana-Arellano, E., H. Echavarria-Heras, O. FloresUzeta \& E. Nieto-García. 2002. Experimental transplant of Zostera marina shoots in Punta Banda estuary B.C. México: production parameters and associated benthic fauna. Ocean. East. Pac. 2: 99-105.

Solana-Arellano, E., H. Hechavarría-Heras \& M.E. Gallegos-Martínez. 2003. Improved leaf area index based biomass estimations for Zostera marina L.J. Math. Med. Biol. 20: 367-375.

Solana-Arellano, E., H. Echavarria-Heras, M.E. GallegosMartínez \& O. Flores-Uzeta. 2004. The role of biotic and abiotic variables determining demographic processes in an eelgrass meadow. Bull. South. Calif. Acad. Sci. 103: 12-20.

Tegner, M. \& P. Dayton. 1987. El Niño effects on Southern California kelp communities. Adv. Ecol. Res. 17: 243-279.

Umebayashi, O. 1988. Individual growth of vegetative shoots of eelgrass Zostera marina. Bull. Tokai Reg. Fish. abs. Tokyo. No. 125.

Valiela, I., K. Foreman, M. LaMontagne, D. Hersch, J. Costa, P. Peckol, B. Demeo-Anderson, C. D’Avanzo, M. Babione, C. Cham, J. Brawley \& K. Lajtha. 1992. Coupling of watershed and coastal waters: Sources and consequences of nutrient enrichment in Waquoit Bay, Massachusetss. Estuaries. 15: 443-457

Von Bertalanffy, L. 1957. Quantitative laws in metabolism and growth. Quart. Rev. Biol. 32: 217-231.

Werner, J.K. \& J.B. Zedler. 2002. How sedge meadow soils, microtopography, and vegetation responds to sedimentation. Wetlands 22: 451-466.

Wharton, C.H. 1970. Southern River Swamp. Georgia State University, Atlanta, Georgia, USA.

Zimmerman, R.C., J.L. Reguzzoni, S. Wyllie-Echeverria, M. Josselyn \& R.S. Alberte. 1991. Assessment of environmental suitability for growth of Zostera mari$n a$ L. (eelgrass) in San Francisco Bay. Aquat. Bot. 39: 353-366. 
